\title{
Best practices for pervious concrete mix design and laboratory tests
}

\section{Boas práticas para dosagem e testes laboratoriais em concreto permeável}

F. B. P. COSTA a, b

fernanda.bpc@gmail.com

A. LORENZI alexandre.lorenzi@ufrgs.br

L. HASELBACH c Ihaselbach@lamar.edu

L. C. P. SILVA FILHO ${ }^{b}$ Icarlos66@gmail.com

\begin{abstract}
Pervious concrete may be used for stormwater management since it allows the water to pass through its interconnected macropores into stormwater systems or soils below. However, there is a need for additional standards related to pervious concrete prior to its widespread use, and there are many aspects related to mix design for desired properties, compaction methods, and test procedures that are not yet completely understood. These variables may significantly affect the functional and mechanical performance of the material. In this paper, mix designs and test specimen preparation techniques were evaluated. The IBRACON method for mixture design was used to obtain the mixture proportions and the calculated density for the desired porosity of $25 \%$. In addition, two different types of specimens (cast or cored) and compaction methods (roller or Proctor hammer compacted) were performed. The density of each specimen was controlled to obtain the same calculated density. Several tests were conducted to compare the following variables: density, porosity, surface infiltration rate, permeability and compressive strength. Additionally, the effects of mortar capping versus neoprene-rubber caps on compressive strength measurements of pervious concrete were evaluated. The experimental results showed that cast specimens have more consistent results than cores. The design method studied with strict control of density was efficient to obtain the desired porosity mainly for cast specimens. The roller leads to a more compacted top surface resulting in a decrease in the infiltration rate and permeability of the cores. The mortar capping method is more consistent than the other.
\end{abstract}

Keywords: pervious concrete, mix design, laboratory procedures, compaction method.

\section{Resumo}

O concreto permeável é um material de potencial para ser utilizado no gerenciamento de águas pluviais, uma vez que permite a percolação da água através de seus macroporos interconectados, seja para sistemas de águas pluviais ou para o próprio solo. No entanto, há uma necessidade de normas adicionais relacionadas ao material para seu uso difundido e, ainda, há muitos aspectos relacionados aos parâmetros de dosagem para propriedades desejadas/projetadas, método de compactação e procedimentos laboratoriais, que ainda não foram completamente compreendidos. Tais variáveis podem afetar significativamente o desempenho funcional em termos hidráulicos e mecânicos do material. Neste trabalho, o método do IPT/EPUSP para dosagem foi utilizado para obter as proporções de mistura e a densidade calculada, para uma porosidade desejada de $25 \%$. Além disso, dois tipos diferentes de amostras (moldadas e extraídas) e métodos de compactação (Proctor e rolo) foram realizados. A densidade de cada amostra foi controlada para obter a mesma densidade calculada. Diversos testes foram realizados para comparar as seguintes variáveis: densidade, porosidade, taxa de infiltração, permeabilidade e resistência à compressão. Além disso, foram avaliados os efeitos do tipo de capeamento (com argamassa e com borracha de Neoprene) nos corpos de prova submetidos ao ensaio de compressão. Os resultados experimentais mostram que os corpos de prova moldados apresentam resultados mais consistentes que as amostras extraídas. O método de dosagem, com controle rigoroso da densidade, foi eficiente para obtenção da porosidade desejada, principalmente para os corpos de prova moldados. O rolo conduz a uma superfície superior mais compacta, o que resulta na diminuição da taxa de infiltração e permeabilidade para as amostras extraídas. O capeamento dos corpos de prova com argamassa apresenta resultados mais consistentes.

Palavras-chave: concreto permeável, dosagem, procedimentos laboratoriais, método de compactação. 


\section{Introduction}

Pervious concrete $(\mathrm{PC})$ is a special type of concrete pavement mainly composed of narrowly graded coarse aggregate and cementitious materials, which provides an interconnected macropore internal structure [1-4]. The volume of connected pores is typically in the range of $15-35 \%$ sufficient to facilitate the flow of water through the pavement layer $[1,2,4]$. PC is increasingly used in the United States and Japan due to its environmental benefits, such as controlling stormwater runoff, restoring groundwater supplies, and reducing water and soil pollution [1]. In addition, it can reduce urban heat island effects and acoustic noise in roads [5,6].

$\mathrm{PC}$ is not usually as strong as traditional concrete for similar mixes and thicknesses. The pore structures that allow water to flow through the material also decrease its strength [7]. As the strength of PC depends mainly on its porosity, which can vary throughout, its structural performance is more variable than traditional concrete [8]. Therefore, the use of PC is typically restricted to lower-strength applications, such as sidewalks, parking lots, recreational spaces and subbases for conventional pavements. Furthermore, the implementation of $\mathrm{PC}$ as a pavement material in many countries (especially emerging countries) is limited due to the lack of standardized techniques for material preparation and testing, and also construction practices [9].

Currently, PC mixtures are proportioned to achieve a design range of porosity in order to achieve an initial water permeability of the pavement, while maintaining sufficient mechanical performance. The associated pore size characteristics with a usual range of 2 to $8 \mathrm{~mm}$ are then related to the aggregate type, size and distribution, and the method of compaction [2].

Some current methods used for design of PC mixtures are from the American Concrete Institute [2], Zouaghi's method [10], Zheng method [11], Nguyen's method [12], and Taguchi's method [13] These design methods consider different parameters. Some of them do not take into account the water to cementitious (w/c) ratio and the effect of compaction on the properties of PC, etc. This leads to a non-standard mixture proportion application. In this study, the IBRACON method [14] is used to determine the mix proportions of PC. As well known, the method is simple and gives the cement content, aggregate content, water content, and density of the fresh

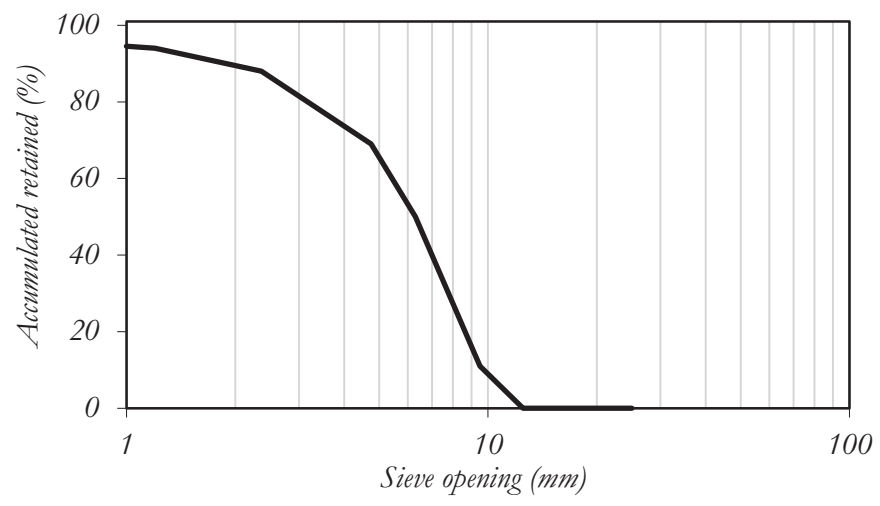

Figure 1

Particle-size distribution of aggregate mixture. The method can be applied to any concrete with a slump of zero $\mathrm{mm}$ to self-compacting concrete. The difference in applying this method from traditional concrete to PC is considering in the cement consumption equation the desired porosity. Although mixture proportioning is a major contributing factor, the compaction effort also directly affects the porosity [15]. As mentioned by Ibrahim et al. [7], it is important to emphasize that the desired porosity is achieved by both factors, i.e. controlling the aggregate proportions and properties, as well controlling the level of compactive effort. The conventional methods used in traditional concrete are not recommended to apply to PC mixtures as they may not be representative and consistent. For instance, the casting technique using a rod has been found to be inappropriate for laboratory PC specimens [16]. At present there is no standard test method to evaluate the compressive and flexural strength of PC. One suggested method considers a cylindrical traditional sample size $(10 \times 20 \mathrm{~cm})$ with a compact effort of the fresh mixture in two layers providing twenty blows per layer using the standard Proctor hammer [8]. According to Chandrappa et al. [9], this method can cause the crushing/ breaking of the coarse aggregate near the top surface due to the impact generated by the Proctor hammer. Additionally, it can result in an inaccurate representation, since the compaction method of $\mathrm{PC}$ pavement in situ is made with a roller in only a single layer. On the other hand, this method may reduce the scatter in the test results due to the decrease of vertical porosity effect [16]. According to Gaedicke et al. [17], the use of a Proctor hammer to compact PC has shown more consistent results.

The Proctor hammer has been used to compact specimens in different ways, i.e. using different types of specimens, blows, and lifts [17-22]. There is a lack of studies that compare cast and cored specimens compacted using the Proctor hammer as recently proposed and rolled specimens to represent in situ situations. In this context, research needs to be conducted to evaluate and compare both of the design and compaction methods that have been mentioned. Therefore, we aim to (i) simplify the design of PC mixtures utilizing the IBRACON method for mixture proportion; (ii) verify the efficiency of the design method for both cast and cored specimens in order to obtain the desired density and porosity; (iii) correlate results by the different compaction methods (Proctor and roller) of cast and cored specimens; and (iv) determine the effects of mortar capping and neoprene-rubber on compressive strength measurements of PC. In the present paper, we also show an adapted method to determine the infiltration of PC cylindrical specimens. With the results obtained in this paper, we intend to provide a comparison between laboratory techniques and the unique variations.

\section{Materials and experimental program}

\subsection{Materials and mix design}

The materials used in the PC mixtures included high early Portland cement (CP-V ARI MAX), basalt aggregate and a rheologymodifying admixture for PC. The aggregate used in this research has a lamellar shape and it is composed of $30 \%$ of fines $(<4.75$ $\mathrm{mm}$ ). A previous study has shown that this aggregate does not impact the hydraulic functionality of PC [23]. The aggregate grading curve is shown in Figure 1. The nominal maximum size is 
Table 1

PC mix proportion

\begin{tabular}{|c|c|}
\hline Material & Amount \\
\hline CP-V ARI MAX $\left(\mathrm{kg} / \mathrm{m}^{3}\right)$ & 370.94 \\
\hline Basalt aggregate $\left(\mathrm{kg} / \mathrm{m}^{3}\right)$ & 1483.75 \\
\hline Water $\left(\mathrm{kg} / \mathrm{m}^{3}\right)$ & 96.44 \\
\hline Admixture $\left(\mathrm{ml} / \mathrm{m}^{3}\right)$ & 3635.21 \\
\hline Density $\left(\mathrm{kg} / \mathrm{m}^{3}\right)$ & 1951.13 \\
\hline
\end{tabular}

$12.5 \mathrm{~mm}$, the specific gravity is $2.80 \mathrm{~g} / \mathrm{cm}^{3}$, and the water absorption is $1.3 \%$. The coarse aggregate was incorporated into the mixture in a dry condition. The rheology-modifying admixture used provides a delay of the setting time, and more workability. The admixture is in accordance with the requirements of ASTM C494 [24] as a Type $D$ water-reducer and retarder.

The PC mix proportions were determined using the IBRACON method for a target porosity of $25 \%$. The mass-based aggregate to cementitious material ratio was 4 , and the mass-based water to cementitious material ratio $(\mathrm{w} / \mathrm{c}$ ) was 0.26 (minimum recommended by ACI 522-R-10 [2]). The admixture dosage used was $980 \mathrm{ml}$ per $100 \mathrm{~kg}$ of cementitious material according to the producer's specification. The final PC mixture design is shown in Table 1.

The PC mixture was prepared in a standard concrete mixer with a capacity of 120 liters. The coarse aggregate with a little of the water was first mixed, and then, after a rapid mixing of these materials, the remaining water and the admixture were slowly added. After that, the PC mixture was additionally mixed for about 3 minutes. This mixing sequence was obtained from previous studies performed by the technical group in the laboratory (LEME/UFRGS), in which it was realized that if the all dry materials were placed in the mixer, the subsequent addition of water causes them to stick to the walls of the mixer. Thus, a portion of the water is added to the aggregate so that, when the cement is added, a more homogeneous mixture is obtained with a small amount of the cementing paste sticking to the walls of the mixer. The consistency of the PC mixture obtained in this research is illustrated in Figure 2.

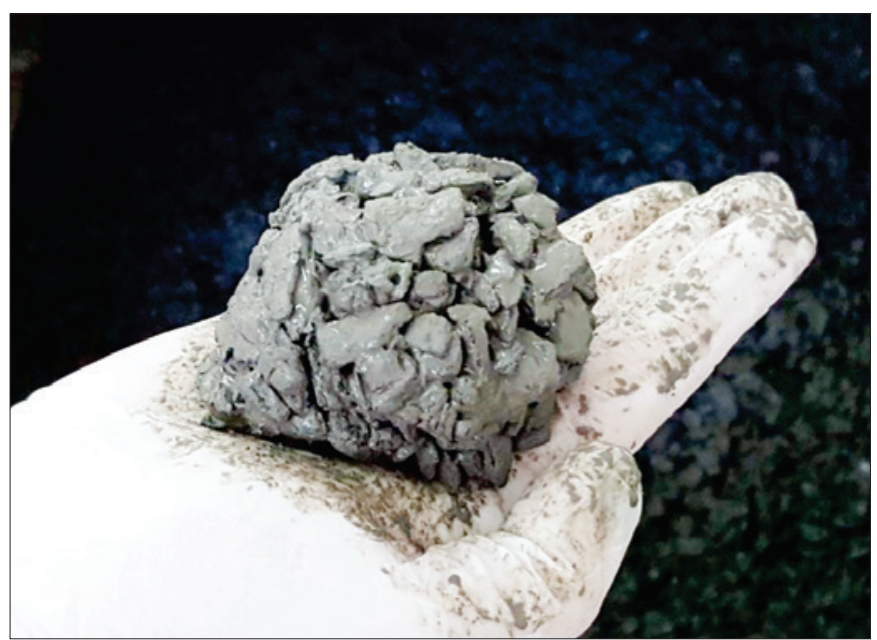

Figure 2

PC consistency

\subsection{Preparation of specimens}

One slab (650 mm length $\times 450 \mathrm{~mm}$ width $\times 200 \mathrm{~mm}$ height) and six cylindrical specimens (200 $\mathrm{mm}$ length and $100 \mathrm{~mm}$ diameter) were cast. The slab was intended to have cores extracted and was compacted using a roller of $48.8 \mathrm{~kg} / \mathrm{m}$ simulating an in situ compaction method. The weight of the slab was controlled to obtain the calculated density shown in Table 1. A total of six cored samples were extracted from the concrete slab to represent the in-place properties of the material. The compaction method used on the cast cylindrical specimens was 20 blows in two layers using a 2.5 $\mathrm{kg}$ standard Proctor hammer as previously mentioned. The total compaction impact by the Proctor hammer is $50 \mathrm{~kg}$ per layer. The weight of each cylindrical specimen based on the calculated density was obtained with this compaction method. The calculated density is shown in Table 1. It is important to emphasize that in previous study evaluated in the laboratory, for densities above 2000 $\mathrm{kg} / \mathrm{m}^{3}$, the Proctor hammer compacting method of 20 blows per layer is not effective enough to achieve the desired density and, consequently, the desired porosity. Depending on the materials used in the PC mixture, it could be necessary more than 20 blows to achieve the desired density. The slab and cylindrical specimens were demolded after 48 hours and cured for 28 days at ambient temperature (about $24 \pm 2{ }^{\circ} \mathrm{C}$ ) and a relative humidity of $50 \pm 5 \%$. The cores samples were extracted 7 days before testing.

\subsection{Test procedures}

\subsubsection{Fresh and hardened density}

The fresh density was determined for the cast cylindrical specimens. The mass of each PC specimen compacted with the Proctor hammer was measured immediately after casting. The fresh density was calculated as described in ASTM C1688 [25]. The hardened density for the cast cylindrical specimens and the cores was calculated according to ASTM C1754 [26]. The masses of both the cast cylindrical specimens and cores were measured and then divided by each specimen bulk volume. This procedure was performed at the age of 27 days ( 1 day before the compressive strength tests).

\subsubsection{Porosity}

The porosity of the cast cylindrical specimens and cores was obtained according to ASTM C1754 [26]. The procedure was also carried out at the age of 27 days. After measuring their dry masses, the cast and cored specimens were submerged in a water bath for 30 minutes. The submerged masses were measured with a hydrostatic balance. The volume of the specimens was determined based on their dimensions measured using a caliper. The porosity $(P)$ was then calculated following the equation:

$\operatorname{Porosity}(\%)=\left[1-\left(\frac{M_{d}-M_{s}}{\rho_{w} \times V}\right)\right] \times 100$

where $M_{d}$ is the dry mass of the specimen in $\mathrm{g}, \mathrm{M}_{\mathrm{s}}$ is the submerged mass of the specimen in $\mathrm{g}, \rho_{\mathrm{w}}$ is the density of water $\mathrm{g} / \mathrm{cm}^{3}$, and $\mathrm{V}$ is the volume of the specimen in $\mathrm{cm}^{3}$. 


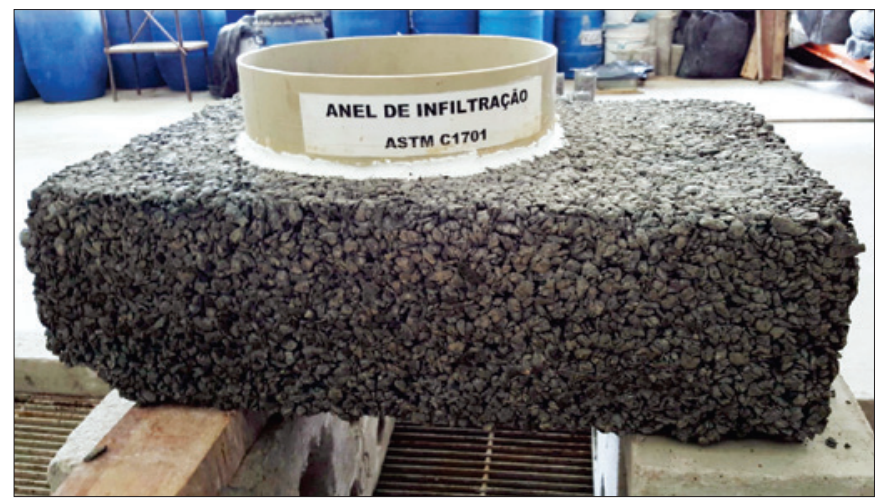

Figure 3

Infiltration test preparation on slab specimen according to ASTM C1701

\subsubsection{Infiltration rate}

Infiltration rate is an important property that is critical for stormwater management application. Therefore, the infiltration rate was measured in two different ways. The traditional infiltration rate test was carried out following the procedures of ASTM C1701 [27]. This test method was performed on the slab specimen at the age of

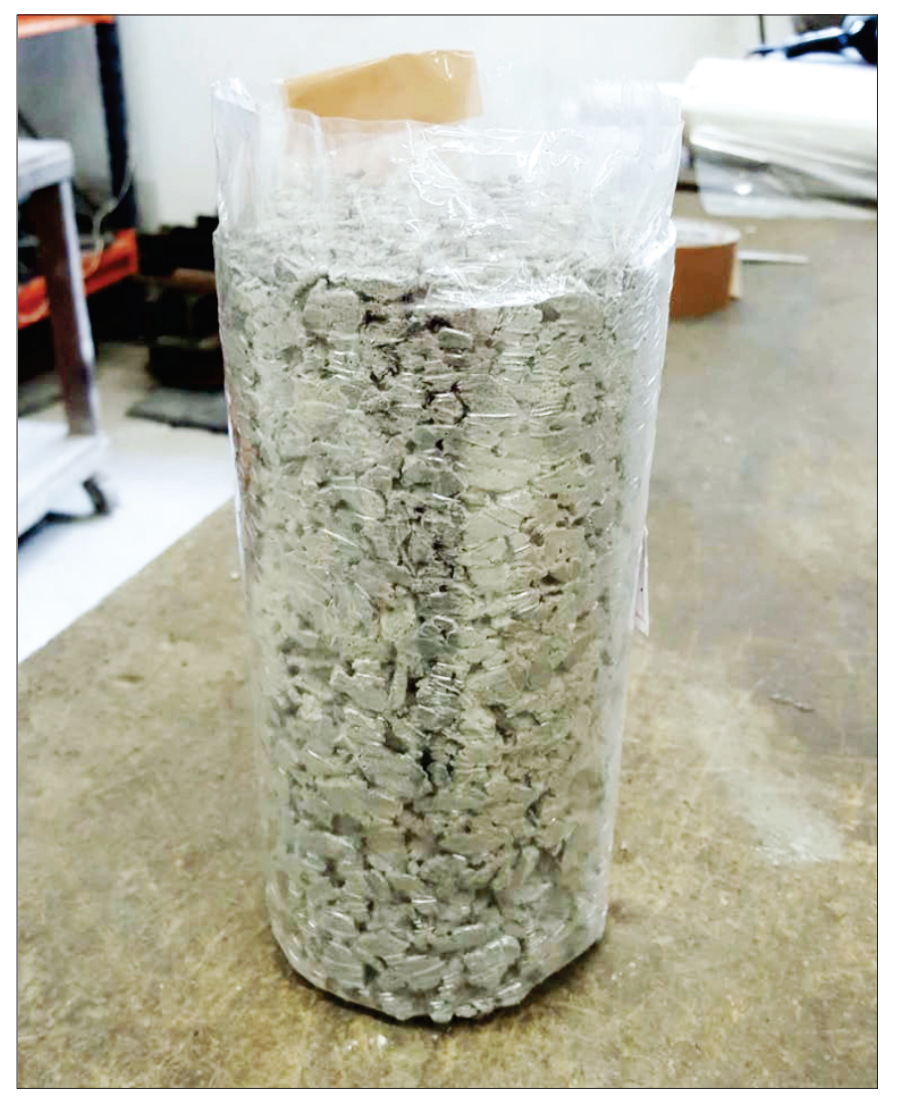

\section{Figure 4}

Infiltration test preparation on cylindrical specimen using a shrink-wrap 7-days (one week before cores extraction). A plastic infiltration ring (with a diameter of $300 \mathrm{~mm}$ and a height of $50 \mathrm{~mm}$ ) was placed at the center of the slab to measure the water infiltration rate in the PC. The bottom edge of the ring was fixed in the PC slab surface with a plumber's putty (Figure 3 ). Then, a prewetting test was evaluated using a total of $3.60 \mathrm{~kg}$ of water, which was placed into the ring and maintained between the two marked lines inside the ring $(10$ and $15 \mathrm{~mm})$. The time recorded was equal to the time the water impacted the PC surface until free water is no longer present on the PC surface. As the elapsed time in the prewetting was less than $30 \mathrm{~s}$, a total of $18 \mathrm{~kg}$ of water was used in the test. The test was then repeated three times to obtain an average time to determine the infiltration rate.

For the cast cylindrical specimens, an infiltration test was performed using shrink-wrap to seal the sides of the specimens (Figure 4). Two lines of 10 and $15 \mathrm{~mm}$ was also marked above the PC surface, inside the shrink-wrap, to maintain the water head during the test. The quantity of water was adapted from the recommended by the ASTM C1701 [27] to the diameter of $100 \mathrm{~mm}$ corresponding to the specimen. The prewetting was also performed with $1.2 \mathrm{~kg}$ of water. As the elapsed time in the prewetting was less than $30 \mathrm{~s}$, a total of $6 \mathrm{~kg}$ of water was used in the test. The test was then repeated three times to obtain an average time to determine the infiltration rate. After cored extraction, this same procedure used for the cast specimens was carried out and compared to the results obtained for the slab. This test was performed at the age of 27 days.

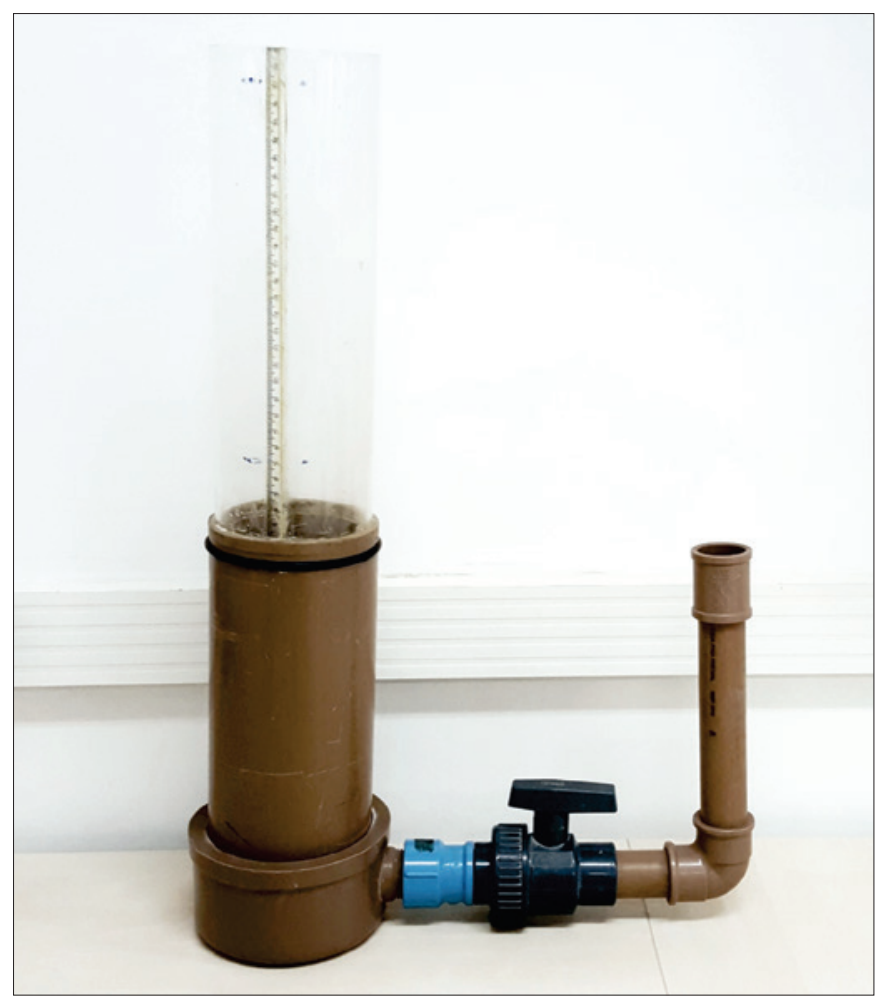

Figure 5

Falling-head permeameter 
In both cases (slab and cylindrical specimens), infiltration rate (I) was determined according to the following equation:

$I(m m / h)=\frac{K \times M}{D^{2} \times t}$

where $\mathrm{M}$ is the mass of infiltrated water in $\mathrm{kg}, \mathrm{D}$ is the diameter of infiltration in $\mathrm{mm}, \mathrm{t}$ is the recorded time related to the water infiltration in $\mathrm{s}$, and $\mathrm{K}$ is factor needed to convert the recorded data, with a value of 4583666000 in SI units.

\subsubsection{Permeability}

A falling-head method may also be used to measure permeability in PC [28]. For the test, a falling-head permeameter was designed in the laboratory as showed in Figure 5. The cast and cored specimens were wrapped with a flexible polyethylene foam membrane to impede water infiltration between the surface of the sample and the apparatus. The test was performed at the age of 27 days. Each specimen was carefully placed in the permeameter. The time for the water to flow through the samples was recorded at the initial $\left(h_{1}\right)$ and final $\left(h_{2}\right)$ levels marked in the permeameter. The coefficient of permeability $(\mathrm{K})$ was calculated using Darcy's law as given below:

$K(\mathrm{~cm} / \mathrm{s})=\frac{a \times L}{A \times t} \times \log _{10}\left(\frac{h_{1}}{h_{2}}\right)$

where a is the cross-sectional area of standpipe in $\mathrm{cm}^{2}, \mathrm{~L}$ is the length of sample in $\mathrm{cm}, \mathrm{A}$ is the cross-sectional area of the sample in $\mathrm{cm}^{2}, \mathrm{t}$ is the recorded time from $\mathrm{h}_{1}$ to $\mathrm{h}_{2}$ in $\mathrm{s}, \mathrm{h}_{1}$ is the initial water level equal to $27 \mathrm{~cm}$, and $h_{2}$ is the final water level equal to $5 \mathrm{~cm}$.

\subsubsection{Compressive strength}

The compressive strength tests were performed according to ABNT NBR 5739 [29] at the age of 28 days. As the PC specimens have an irregular surface due to aggregate overhang, two procedures for the compressive strength test were considered. The first one was using neoprene-rubber pads at the specimen ends and the other one was capping the surfaces with a polymeric mortar. The objective is to evaluate the more effective method to the distri-

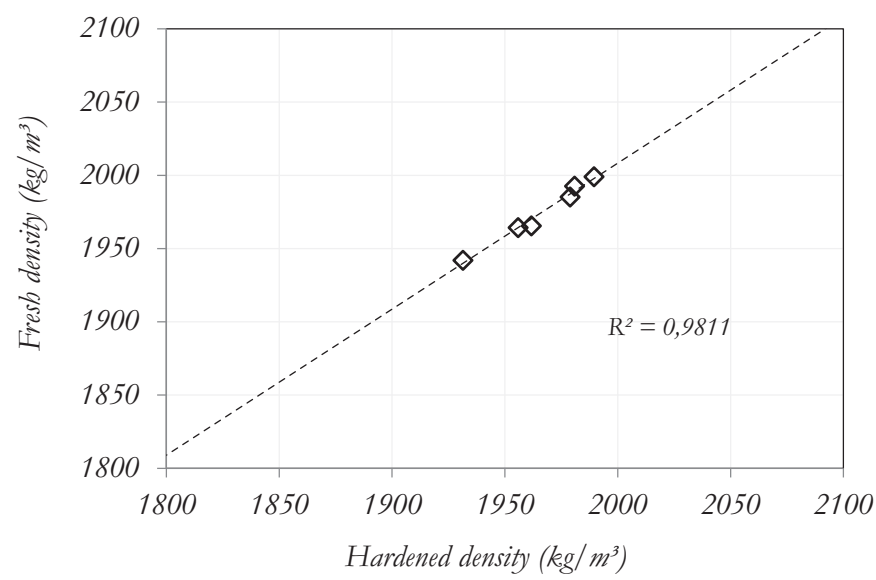

\section{Figure 6}

Fresh density vs. hardened density of cast cylindrical specimens bution of the compression force. Three specimens from the casts and cores of the total six were used for each procedure.

\section{Results and discussions}

\subsection{Fresh vs. hardened density for cast specimens}

The fresh density was measured for the cast cylindrical specimens since it was not possible to evaluate the fresh density for the cored specimens, which were extracted from the slab once hardened. The fresh density was measured immediately after casting. The relation between fresh and hardened density for the cast specimens is shown in Figure 6. It can be observed that the fresh density was slightly higher than the hardened density as expected. This fact is attributed to the water loss by the hydration products. In the graph, the following regression equation was obtained:

$D_{h}=0.9843 D_{f}+22.666$

where $D_{h}$ and $D_{f}$ are the hardened and fresh density for PC cast cylindrical specimens, respectively. Since $R^{2}$ is close to 1.0 , the average decrease in the hardened density is $0.43 \%$. The designed (theoretical) density was $1950 \mathrm{~kg} / \mathrm{m}^{3}$ and the average fresh density obtained was $1975 \mathrm{~kg} / \mathrm{m}^{3}$, which represents an average difference of only $1.21 \%$. This fact demonstrates that the design method and compaction method were efficient in obtaining the desired density for the mix design analyzed.

\subsection{Hardened density vs. porosity}

Figure 7 shows hardened density over porosity for the cast and cored specimens. It can be observed that the relation between the hardened density and porosity was affected by the compaction method. The linear curves had a different slope. The cast specimens showed a hardened density and porosity near to the desired. On the other hand, the cores specimens showed lower densities and, consequently, higher porosities. Further verification analyses with ANOVA confirmed that the cast and cored specimens are not similar in relation to density and porosity considering this method

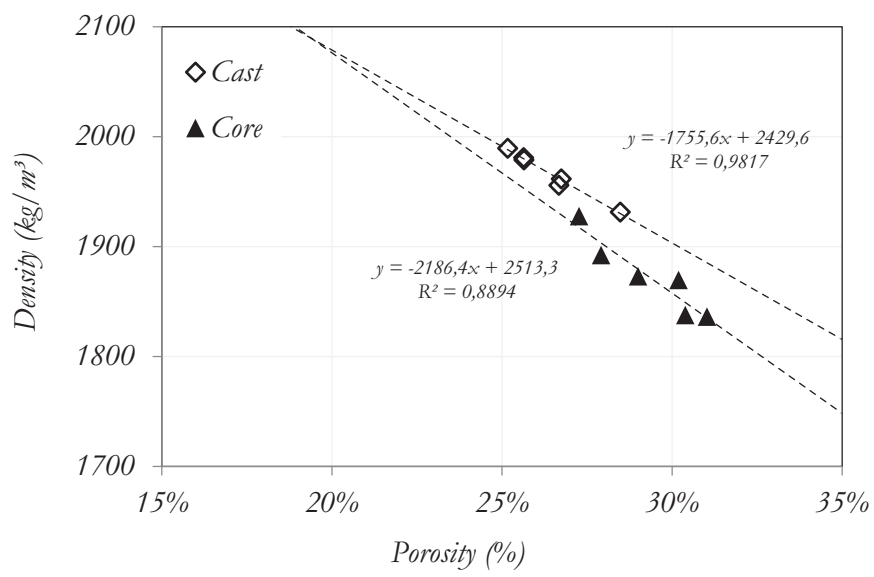

Figure 7

Hardened density vs. porosity of cast and cored specimens 
Table 2

Statistical results for cast and cored specimens (physical and hydraulic properties)

\begin{tabular}{|c|c|c|c|c|c|}
\hline \multicolumn{2}{|c|}{ Specimen type } & $D\left(k g / m^{3}\right)$ & $\mathbf{P}(\%)$ & $\mathrm{I}(\mathrm{mm} / \mathrm{h})$ & $\mathrm{K}(\mathrm{cm} / \mathrm{s})$ \\
\hline \multirow{3}{*}{ Cast } & Average & 1966.33 & $26.39 \%$ & 24936 & 1.48 \\
\hline & $\mathrm{SD}$ & 21.23 & 0.01 & 0.11 & 0.32 \\
\hline & $\mathrm{CV}$ & $1.08 \%$ & $4.54 \%$ & $15.85 \%$ & $21.87 \%$ \\
\hline \multirow{3}{*}{ Cored } & Average & 1872.78 & $29.30 \%$ & 8839 & 0.87 \\
\hline & $\mathrm{SD}$ & 34.55 & 0.01 & 0.12 & 0.22 \\
\hline & $\mathrm{CV}$ & $1.84 \%$ & $5.09 \%$ & $49.02 \%$ & $25.62 \%$ \\
\hline Cast vs. Cored & $\mathrm{p}$-value & 0.0002 & 0.0039 & 0.0001 & 0.0035 \\
\hline
\end{tabular}

of compaction. The summary statistical results obtained for each cast and cored specimens are shown in Table 2.

\subsection{Infiltration rate vs, porosity}

The infiltration rate was measured in the slab before cored extraction. The average value between the three readings performed was $0.35 \mathrm{~cm} / \mathrm{s}$. Figure 8 shows the infiltration rate versus porosity for cast and cored specimens that was measured using the shrink-wrap. The dotted line in the graph represents the slab infiltration rate. It can be seen that the difference in the infiltration rate between the cast and cores specimens is quite evident, even when the porosity is in the same range. There is more variability in the results obtained for cores than cast specimens. The increase in porosity may not result in an increase in the infiltration rate for the cores. This fact can be attributed to the compaction method. The roller leads to a more compacted surface, which can restrict the passage of water on the top surface, reducing the infiltration rate. Figure 9 shows the effect of the compaction method on the specimen appearance. It is possible to note that the compaction method has a direct influence on the pore connectivity and tortuosity (mainly on the top). In previous studies, cores that were compacted in one single lift, the porosity increased along the depth [30]. This fact can justify the lower infiltration rate but with an increase in the porosity.

The statistical results of infiltration rate obtained for each cast and cored specimen are listed in Table 2. The higher coefficient of vari-

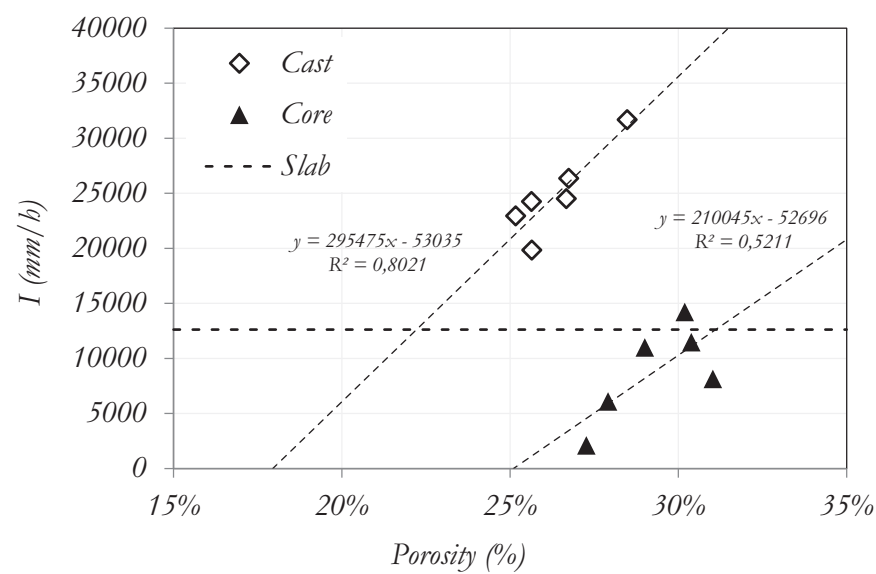

Figure 8

Infiltration rate vs. porosity of cast

and cored specimens ation (CV) obtained for cores confirms the variability in the results. The $R^{2}$ obtained on the graph demonstrate that only $52 \%$ of the dependent variable can be explained by the linear regression in the model. This may be attributed to the contact area of the roller. During the initial pass of the roller, the contact area is large and decreases for subsequent passes, which produces low compaction pressure during the initial pass and increase for later passes [31]. The differences in the pressure caused by the roller passing may be the reason for the differences in infiltration rate obtained between the cores. This means that in some parts of the slab, a more compacted surface can be obtained than other parts, which makes some cores with less infiltration on the surface.

\subsection{Permeability vs. porosity}

Figure 10 shows the permeability versus porosity for cast and cored specimens. The model for permeability vs. porosity is also represented by a linear relationship. The difference in the permeability between the cast and cored specimens is also evident, even

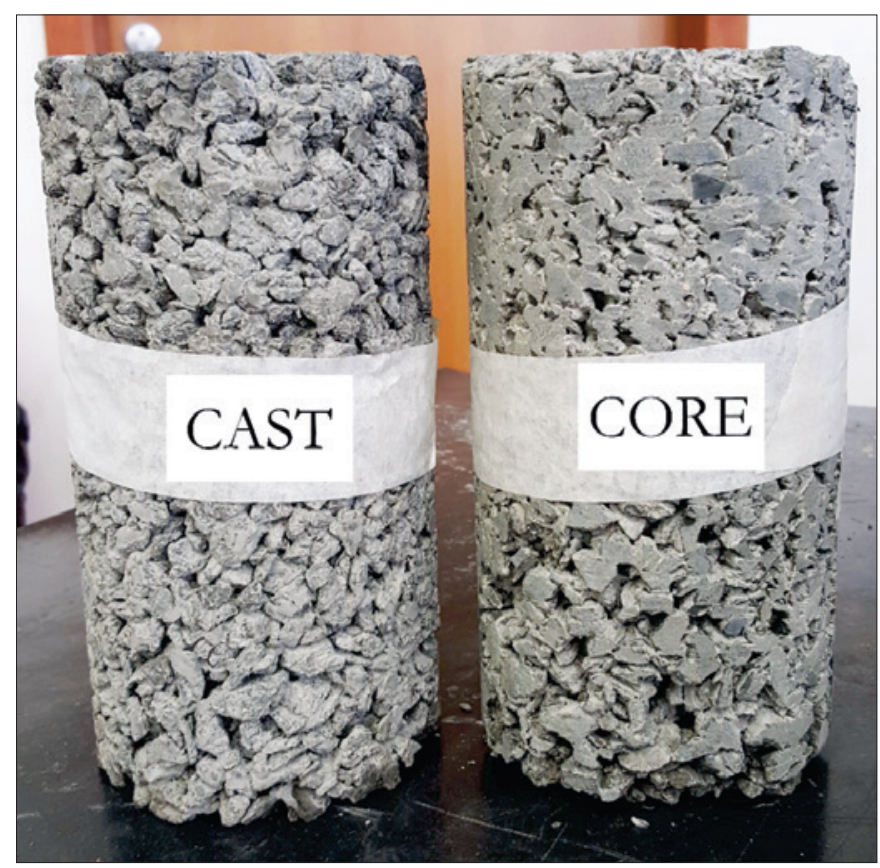

Figure 9

Cast and cored specimen appearances 


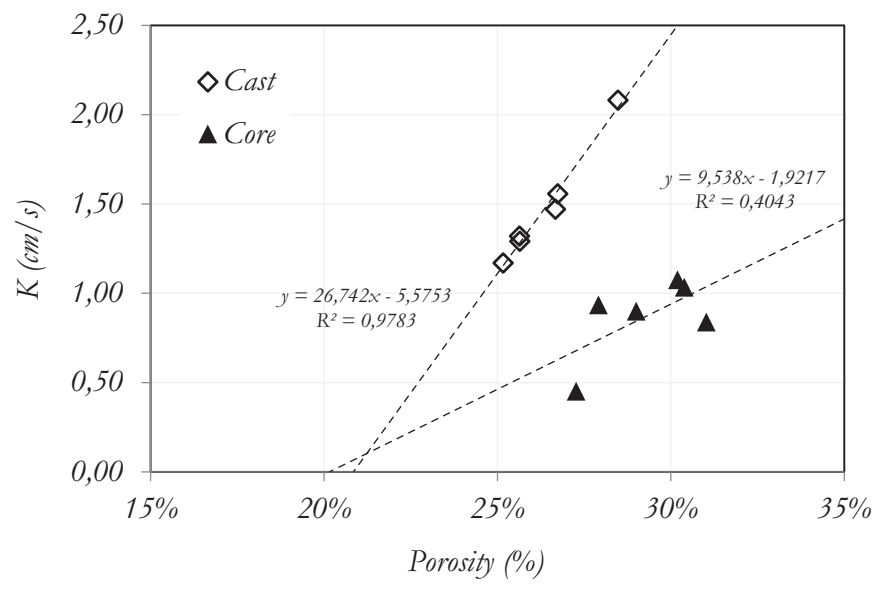

Figure 10

Infiltration rate vs. porosity of cast and cored specimens

when the porosity is in the same range. Like observed in infiltration rate, there is more variability in the results obtained for cores than cast specimens. The same reason that justifies the infiltration rate results can explain the results obtained for the permeability test. The permeability in the cores decreases due to the use of the roller, which increases the compaction on the slab top surface. The cored top surface is less permeable even though the porosity is higher, which is conferred by the bottom part of the specimen. The cast and cores specimens showed a permeability range of 1.17 to $2.08 \mathrm{~cm} / \mathrm{s}$ and 0.84 to $1.08 \mathrm{~cm} / \mathrm{s}$, respectively. Both ranges are in accordance to the ones observed by other authors in the literature using the falling-head apparatus. Schaefer et al. [32] obtained a measured hydraulic conductivity ranged between about $0.01 \mathrm{~cm} / \mathrm{s}$ and $1.5 \mathrm{~cm} / \mathrm{s}$. Montes and Haselbach [33] obtained a range between $0.014 \mathrm{~cm} / \mathrm{s}$ and $1.19 \mathrm{~cm} / \mathrm{s}$. Table 2 shows the statistical results of permeability obtained for each cast and cored specimens. For both, the CV obtained was over $20 \%$. However, by the graph, the $R^{2}$ for cast specimens is 0.97 , which indicates that the relationship between the permeability and porosity for the cast specimens is well-represented by the linear model. On the other hand, the model is not representative for the cores, since only $40 \%$ of the dependent variable can be explained by the linear regression. The differences in the pressure caused by the roller passing can also be the reason for the results variability.

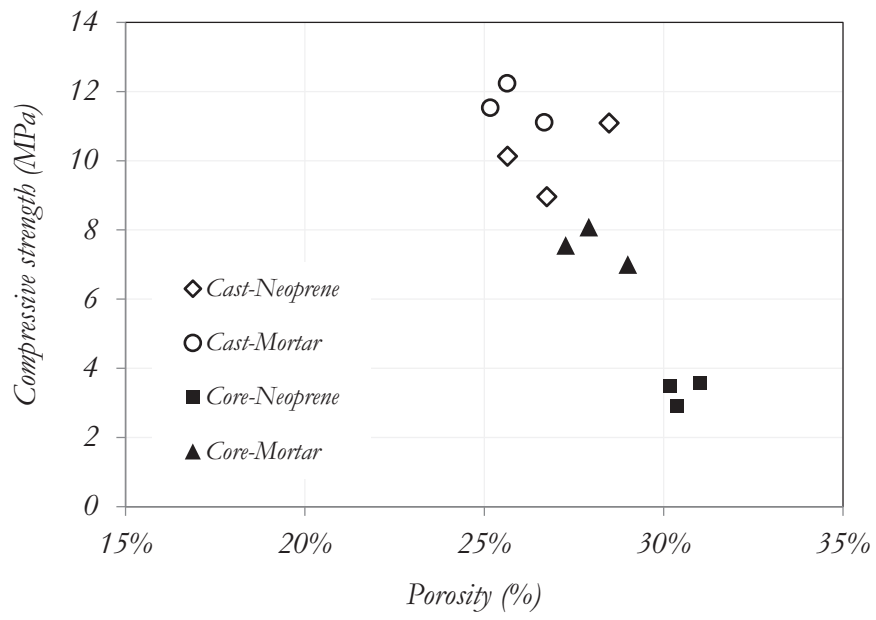

Figure 11

Compressive strength vs. porosity of cast and cored specimens by capping method

\subsection{Compressive strength vs. porosity and the effect of capping method}

Figure 11 shows the compressive strength over porosity for cast and cores considering both mortar capping and the use of neoprene-rubber. Of the total six, three specimens were used for each technique to the compressive test. It can be observed that regardless the method used, the compressive strength of cast specimens is higher than cores. This fact can possibly be attributed to the decrease in the vertical porosity by the compaction method using the Proctor hammer.

The technique used for the compressive test is also another factor that directly influences the compressive strength. It must be considered that due to the non-regularization surface of the pervious concrete specimen the results are very affected. In some cases, this might cause a stress concentration point during the compressive test and, consequently, change the fracture behavior of the sample. This fact is highlighted for the cores. When extracted, the bottom surface may be damaged by the hole saw because of its higher porosity. The results showed in Figure 11 confirms the influence of mortar capping and the use of neoprene-rubber. Table 3 shows the statistical results for compressive strength considering both techniques. The $p$-value obtained with ANOVA shows that the use of

Table 3

Statistical results for compressive strength of cast and cored specimens

\begin{tabular}{|c|c|c|c|}
\hline \multicolumn{2}{|c|}{ Specimen type } & Mortar capping & Neoprene-rubber \\
\hline \multirow{3}{*}{ Cast } & Average & 10.06 & 11.63 \\
\cline { 2 - 4 } & SD & 1.07 & 0.57 \\
\cline { 2 - 4 } & CV & $10.60 \%$ & $4.91 \%$ \\
\hline Mortar vs. Neoprene & P-value & 3.31 & 7.54 \\
\hline \multirow{2}{*}{ Cored } & Average & 0.36 & 0.54 \\
\cline { 2 - 4 } & SD & $10.87 \%$ & $7.16 \%$ \\
\cline { 2 - 4 } & CV & \multicolumn{2}{|c|}{0.0004} \\
\hline
\end{tabular}


mortar capping and neoprene-rubber are not similar in relation to the compressive strength for cores, but can be considered not significative for the cast specimens ( $p$-value $>0,05$ ). Thus, there is no significative influence on the technique applied to cast specimens on the compressive strength. Figure 12 shows an example of the specimen rupture by the technique applied. When the specimens are not capped with mortar, the use of neoprene-rubber is not enough to distribute the compression force, causing a local rupture.

\section{Conclusions}

The present paper was conducted to evaluate the influence of laboratory methods used in order to obtain desired properties of $\mathrm{PC}$ and to compare two types of compaction methods in cast and cored specimens. This study contributes to the understanding of the variability in the results in studies on pervious concrete specimens based on several different laboratory methods used. Thus, the following conclusions may be drawn:

- The design method studied with strict control of density was efficient in order to obtain the porosity mainly for cast specimens. The average porosity obtained for the cast and cores was $26.39 \%$ (only $1.39 \%$ higher than desired value), and $29.30 \%$, respectively. The desired value of porosity is more difficult to obtain for the cores due to the horizontal variability in the slab and also due to not being able to as effectively control density as in a cast specimen. Care must be taken during the specimens casting (i.e. controlling their masses) in order to obtain the density, and consequently, the desired porosity;

- The roller leads to a more compacted top surface compared to the Proctor hammer, which decreases the infiltration rate and permeability of the specimens. Besides, using only single-lift-

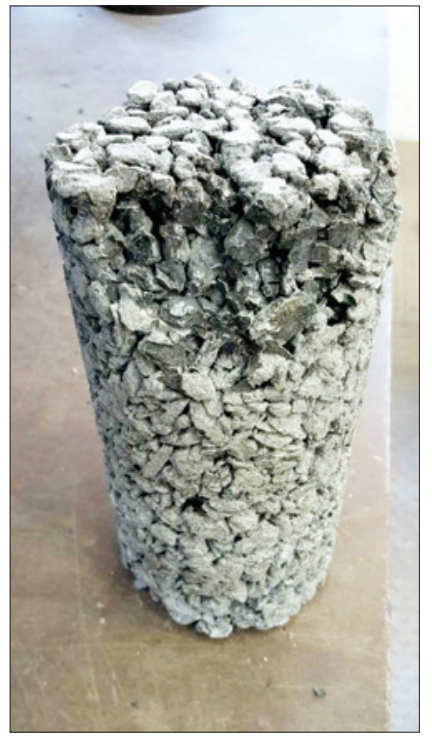

(a) Not capped (neoprene-rubber)

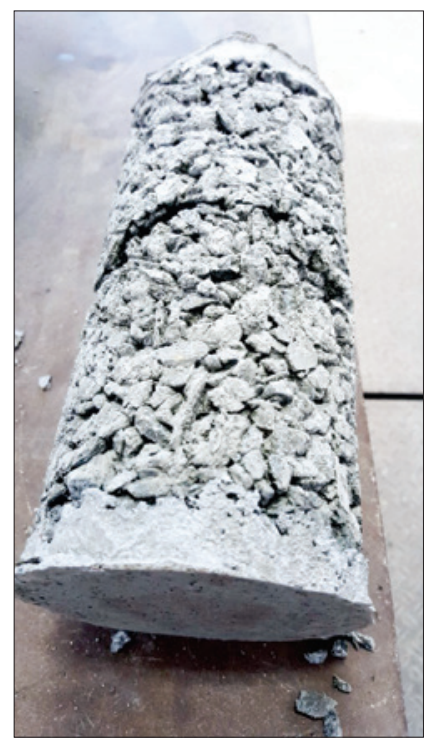

(b) Capped with mortar

\section{Figure 12}

The influence of technique applied to compressive test compacted specimen results in differences in vertical porosity. This fact is important to in situ situations to facilitate the percolation of water between the PC pavement and the base layer but can cause more variability data for laboratory analysis. This compaction method also generates differences in the pressure caused by the roller passing, which also causes variations in the results between cores. In real life applications, the differences in vertical porosity of the pervious concrete pavement are important when it comes to maintenance in service life. When it gets clogged, the top surface is easier to get clean while the interfacial area between the pavement and the base layer is not possible to access. Thus, a higher porosity on the bottom facilitates the percolation of water and sedimentation particles;

- Proctor-hammer-compacted cylinders presented more consistent results due to a more uniform vertical porosity. This method was well-represented by the linear models utilized on all graphs, which facilitates properties estimation;

- The use of neoprene-rubber to distribute the compressive stresses in the specimens is not recommended for cores. The technique of using mortar capping leads to a more regular surface and enables the uniform distribution of compressive stresses in the specimens. However, both techniques can be used for cast specimens due to the more regular surface obtained with the compaction method, facilitating laboratory procedures.

In sum, the compaction method using the roller is more representative of the in situ procedures. However, by using Proctor-hammercompacted cylinders, it is possible to reduce the variation coefficient and enable the comparison of other variables - such as the incorporation of fibers, admixtures and supplementary cementitious materials. Besides, it is easier to produce in the laboratory than cored extraction. Finally, it is important to emphasize that the results presented in this paper are valid only for the mix analyzed and cannot be extrapolated to other mixes unless studied previously.

\section{Acknowledgements}

The authors would like to thank the Laboratory of Test and Structural Models (LEME) of the Federal University of Rio Grande do Sul (UFRGS) where the experimental tests and analyses were conducted. The authors also would like to acknowledge the support of FAPERGS through PRONEX program, which financed the creation and operation of NEXCES, UFRGS's Excellence Center for Special Concretes.

\section{References}

[1] TENNIS, P.D.; LEMING, M.L.; AKERS, D.J. Pervious Concrete Pavements. EB302. Portland Cement Association, Skokie, Illinois, 2004. 36 p.

[2] ACl 522R-10. Report on pervious concrete. American Concrete Institute, 2010.

[3] NEITHALATH, N.; SUMANASOORIYA, M. S.; DEO, O. Characterizing pore volume, sizes, and connectivity in pervious concretes for permeability prediction. Materials Characterization, v.61, 2010, p.802-813.

[4] YAHIA, A.; KABAGIRE, D. New approach to proportion pervious concrete, Construction and Building Materials, v.62, 2014, p.38-46. 
[5] YANG, J.; JIANG, G. Experimental study on properties of pervious concrete pavement materials. Cement and Concrete Research, v.33, 2003, p.381-386.

[6] LORENZI, A.; HASELBACH, L.; SILVA FILHO, L. C. Field data for heat island mitigation by pervious concrete in Porto Alegre. In: Proceedings of the $3^{\text {rd }}$ International Conference on Best Practices for Concrete Pavements, 2015, p. 1-11.

[7] IBRAHIM, A.; MAHMOUD, E.; YAMIN, M.; PATIBANDLA, V. C. Experimental study on Portland cement pervious concrete mechanical and hydrological properties. Construction and Building Materials, v.50, 2014, p.524-529.

[8] CROUCH, L. K.; CATES, M. A.; DOTSON. V. J.; HONEYCUTT, K. R.; BADOE, D. Measuring the effective air void content of Portland cement pervious pavements. Cement and Concrete Aggregates, v.25, n.1, 2003, p.16-20.

[9] CHANDRAPPA, A. K.; BILIGIRI, K. P. Pervious concrete as a sustainable pavement material - Research findings and future prospects: A state-of-the-art review. Construction and Building Materials, v.111, 2016, p.262-274.

[10] ZOUAGHI, A. Technological problems of multi-performance porous concrete. In: Proceedings of the $1 \mathrm{st}$ fib congress, 2002, p. 233-42.

[11] ZHENG, M.; CHEN ,S.; WANG, B. Mix design method for permeable base of porous concrete. International Journal of Pavement Research Technology, v.5, 2012, p.102-7.

[12] NGUYEN, D. H.; SEBAIBI, N.; BOUTOUIL, M.; LELEYTER, L.; BARAUD, F. A modified method for the design of pervious concrete mix. Construction and Building Materials, v.73, 2014, p.271-282.

[13] JOSHAGHANI, A.; RAMEZANIANPOUR, A. A.; ATAEI, O.; GOLROO, A. Optimizing pervious concrete pavement mixture design by using the Taguchi method. Construction and Building Materials, v.101, 2015, p.317-325.

[14] HELENE, P.R.L.; TERZIAN, P. Manual de Dosagem e Controle do Concreto. São Paulo: PINI, 349p., 1992.

[15] DEO, O.; NEITHALATH, N. Compressive behavior of pervious concretes and a quantification of the influence of random pore structure features. Material Science \& Engineering, v.528, n.1, 2010, p.402-12.

[16] Haselbach, L.; Freeman, R. Vertical Porosity Distributions in Pervious Concrete Pavement. ACI Materials Journal, v.103, n.6, 2006, p.452-458.

[17] GAEDICKE, C.; MARINES, A.; MIANKODILA, F. A method for comparing cores and cast cylinders in virgin and recycled aggregate pervious concrete. Construction and Building Materials, v.52, 2014, p.494-503.

[18] RIZVI, R.; TIGHE, S. L.; HENDERSON, V.; NORRIS, J. Laboratory sample preparation techniques for pervious concrete. In: Procedures of $88^{\text {th }}$ annual meeting transportation research board, 2009, $16 \mathrm{pp}$.

[19] SUMANASOORIYA, M. S.; NEITHALATH, N. Pore structure features of pervious concrete proportioned for desired porosities and their performance prediction. Cement \& Concrete Composites, v.33, 2011, p. 778-787.

[20] PUTMAN, B. J.; NEPTUNE, A. I. Comparison of test specimen preparation techniques for pervious concrete pavements. Construction and Building Materials, v. 25, n.8, 2011, pp. 3480-3485.
[21] DEO, O.; NEITHALATH, N. Compressive response of pervious concretes proportioned for desired porosities. Construction and Building Materials, v.25, n.11, pp. 4181-4189.

[22] TORRES, A.; HU, J.; RAMOS, A. The effect of the cementitious paste thickness on the performance of pervious concrete. Construction and Building Materials, v.95, n.1, 2015, pp. 850-859.

[23] HASELBACH, L.; DUTRA, V. P.; SCHWETZ, P.; SILVA FIL$\mathrm{HO}$, L. C. P. A pervious concrete mix design based on clogging performance in Rio Grande do Sul. In: $3^{\text {rd International }}$ Conference on Best Practices for Concrete Pavements, Bonito, 2015, Anais, 2015.

[24] AMERICAN SOCIETY FOR TESTING AND MATERIALS. ASTM C494 / C494M-17, Standard Specification for Chemical Admixtures for Concrete, ASTM International, West Conshohocken, PA, 2017.

[25] AMERICAN SOCIETY FOR TESTING AND MATERIALS. ASTM C1688 / C1688M-14a, Standard Test Method for Density and Void Content of Freshly Mixed Pervious Concrete, ASTM International, West Conshohocken, PA, 2014.

[26] AMERICAN SOCIETY FOR TESTING AND MATERIALS. ASTM C1754 / C1754M-12, Standard Test Method for Density and Void Content of Hardened Pervious Concrete, ASTM International, West Conshohocken, PA, 2012.

[27] AMERICAN SOCIETY FOR TESTING AND MATERIALS. ASTM C1701 / C1701M-17a, Standard Test Method for Infiltration Rate of In Place Pervious Concrete, ASTM International, West Conshohocken, PA, 2017.

[28] KEVERN, J. T.; SCHAEFER, V. R.; WANG, K.; SULEIMAN, M. T. Pervious concrete mixture proportions for improved freeze-thaw durability. Journal of ASTM International, v.5, n.2, 2008, 12 pp.

[29] ASSOCIAÇÃO BRASILEIRA DE NORMAS TÉCNICAS. NBR 5739, Concreto - Ensaio de compressão de corpos de prova cilíndricos, Rio de Janeiro, 2007.

[30] MARTIN III, W. D.; KAYE, N. B.; PUTMAN, B. J. Impact of vertical porosity distribution on the permeability of pervious concrete. Construction and Building Materials, v.59, 2014, p.78- 84 .

[31] KEVERN, J. T.; SCHAEFER, V. R.; WANG, K. Evaluation of pervious concrete workability using gyratory compaction. Journal of Materials in Civil Engineering, vol.21, n.12, 2009, $19 \mathrm{pp}$.

[32] MONTES, F.; HASELBACH, L. Measuring hydraulic conductivity in pervious concrete. Environmental Engineering Science, v.23, n.6, 2006, p.960-969.

[33] SCHAEFER, V.; WANG, K.; SULEIMMAN, M.; KEVERN, J. Mix design development for pervious concrete in cold weather climates. Final Report, Civil Engineering, lowa State University, 2006. 